\title{
INCREASING SOIL FERTILITY
}

\author{
Sayimbetov Alisher \\ Doctor of Philosophy (PhD) in Agricultural Sciences, Docent of the Department Farming, \\ Selection and Seed Breeding of Agricultural Crops, Nukus branch of Tashkent State Agrarian \\ University, Nukus, Karakalpakstan, Uzbekistan
}

\author{
Elemesova Nargiza Isataevna \\ Assistant of the Department Farming, Selection and Seed Breeding of Agricultural Crops, Nukus \\ branch of Tashkent State Agrarian University, Nukus, Karakalpakstan, Uzbekistan
}

\author{
Abdimuhammedalieva Indira Jumamuratovna \\ Assistant of the Department of Plant Scince, Forestry and Medicinal Plants, Nukus branch of \\ Tashkent State Agrarian University, Nukus, Karakalpakstan, Uzbekistan
}

Article DOI: https://doi.org/10.36713/epra5175

\begin{abstract}
This article presents information about the importance of using composts prepared in different proportions nowadays to increase and maintain soil fertility. It is written about as a result of the usage and preparation of composts by mixing various organic wastes with phosphogypsum to improve and maintain soil fertility, a certain increase in humus in the soil, a decrease in soil capacity mass and an increase in porosity, the accumulation of nutrients in the soil provide an additional yield of 5-6 $c$ / ha per hectare of cotton.

KEYWORDS: soil, fertility, humus, soil properties, bulk density, porosity, compost, organic fertilizers, various wastes, cotton yield, yield.
\end{abstract}

\section{INTRODUCTION}

In agriculture, it is important to cultivate irrigated lands efficiently and effectively, the main task is to improve and increase soil fertility, to grow abundant and high-quality crops. This has always been one of the most pressing issues.

Currently, as a result of improper use of mineral fertilizers in the soil, there is a sharp change of organic substances in the composition of soil, the amount of humus decreases from year to year, the biological balance of the soil is disturbed and soil fertility decreases. This is causing serious problems in the development of agriculture today.

The experience of world agriculture shows that crop yields are inextricably linked with the amount of fertilizers applied to the soil. The effectiveness of fertilizers is usually noted by the amount of additional yield obtained from the crop.

Quziev R.Q. [3] noted that an increase in humus content in soils plays an important role in increasing not only soil properties but also crop yields. The organic substances removed by the crop causes a decrease in the amount of humus, nitrogen and other nutrients in the soil. Depletion of humus negatively affects the physical condition of the soil. Their density increases, air and water order deteriorates. The nature of the soil humus also changes and its protective function decreases.

Azimbaev S. and others [1] report that the usage of composts prepared from various wastes in irrigated meadow soils in pure form or in combination with mineral fertilizers allows the 
accumulation of large amounts of organic substances in the soil. In the experiment, the reduction of harmful cations in the soil was also achieved due to the use of composts. This shows that the natural minerals and composts used have a positive effect on soil properties.

According to researchers, the use of composts increases the activity of microorganisms as a result of an increase in the amount of humus in the soil, and also increases soil fertility. These allow to grow ecologically clean products in agriculture, increase productivity and increase income $[2 ; 4 ; 5]$.

Humus has a special role in soil fertility. To get a great and high-quality yield from agricultural crops, soil fertility must be high.

In this regard, application of local fertilizers, composts of various compositions and their effective use in the restoration and improvement of fertility of low-yielding soils is one of the most pressing issues today.

Currently, the preparation and usage of composts by mixing various organic wastes to improve soil fertility in the absence of local manures ensures high and ecologically qualitative yields of agricultural crops.

Preparation of composts from various wastes and their usage improves soil fertility and waterphysical properties, as well as increases the yield of cotton.

\section{METHODS OF CONDUCTING THE EXPERIMENT}

Based on the information above, experiments were conducted at the research and training farm of Tashkent State Agrarian University to improve soil properties and increase cotton yields by preparing composts in different proportions from different wastes and applying them at 10 and 20 tons per hectare. The composition of the composts used in the experiment consisted of different wastes, were prepared in 3 different proportions and were applied at 10 and 20 tons per hectare. They are compost-1 (rice husks and sawdust $-25 \%$, cattle manure-25\%, poultry manure- $45 \%$, phosphogypsum-5\%); compost-2 (rice husks and sawdust $-25 \%$, cattle manure- $25 \%$, poultry manure- $35 \%$, phosphogypsum$15 \%$ ); compost-3 (rice husks and sawdust $-25 \%$, cattle manure- $25 \%$, poultry manure- $25 \%$, phosphogypsum-25\%).

The research was conducted on the basis of "Methods of conducting field experiments" (2007).

\section{RESEARCH RESULTS AND DISCUSSION}

One of the main indicators determining its fertility in the soil is its agrophysical properties.
Basically, it is the mechanical composition of the soil, granularity, capacity mass, porosity, water permeability and so on. The physical properties of the soil and the physical processes that take place in it have a major impact on soil formation, fertility, and plant growth and development.

It has been proved by a number of scientists that microbiological processes are also active when the soil ploughing layer is well supplied with moisture, air and nutrients. However, due to various influences, the capacity mass of the soil changes in a peculiar way.

The experiments revealed the effect of different composting norms on changes in soil capacity mass. In the experiment, control (NRK) variant, at the beginning of the action (vegetation) period, the capacity mass in layers of soil 0-30 and $30-50 \mathrm{~cm}$ was $1.33-1.40 \mathrm{~g} / \mathrm{cm}^{3}$, by the end of the cotton growing (vegetation) period, the capacity mass in the 0-30 and 30-50 cm layers of soil increased compared to the initial values $\left(1.38\right.$ and $\left.1.44 \mathrm{~g} / \mathrm{cm}^{3}\right)$.

In the variants of 10 and $20 \mathrm{t} / \mathrm{ha}$ compost-1 on the background of mineral fertilizers at the beginning of the action period the capacity mass of the soil in layers $0-30$ and $30-50 \mathrm{~cm}$ was $1.29-1.27$ and $1.36-1.35 \mathrm{~g} / \mathrm{cm}^{3}$, respectively, it was $0.04-0.06$ and $0.04-0.05 \mathrm{~g} / \mathrm{cm}^{3}$ less than the control variant. By the end of the action period, however, these differences were greater than in Option 1.

At the beginning of the action period in the variants using compost- 2 at 10 and 20 t/ha per hectare, the capacity mass of the soil in layers $0-30$ and $30-50 \mathrm{~cm}$ is $1.28-1.27$ and $1.36-1.34 \mathrm{~g} / \mathrm{cm}^{3}$, respectively, compared to the control variant decreased by $0.05-0.06$ and $0.04-0.06 \mathrm{~g} / \mathrm{cm}^{3}$ and the compost norms decreased by $0.1-0.1$ and $0.2-0.1$ $\mathrm{g} / \mathrm{cm}^{3}$ compared to the manure norms. At the end of the action period, the capacity masses in the above soil layers were $1.33-1.31$ and $1.41-1.39 \mathrm{~g} / \mathrm{cm}^{3}$, respectively, and decreased by $0.05-0.07$ and 0.03 $0.05 \mathrm{~g} / \mathrm{cm}^{3}$ compared to option 1 and by $0.01-0.01$ and $0.01-0.01 \mathrm{~g} / \mathrm{cm}^{3}$ compost norms compared to manure norms. It was found out that at the beginning of the action period in the compost-3 10 and $20 \mathrm{t} / \mathrm{ha}$ variants, the soil capacity mass in layers $0-30$ and 30$50 \mathrm{~cm}$ was $1.29-1.28$ and $1.37-1.36 \mathrm{~g} / \mathrm{cm}^{3}$, and compared to the control decreased by $0.04-0.05$ and $0.03-0.04 \mathrm{~g} / \mathrm{cm}^{3}$. By the end of the action period, these differences were greater than in Option 1.

The study also found the effect of different compost norms on changes in the porosity of lowyielding soils. At the beginning of the action period in the control variant, the porosity in the $0-30$ and 30$50 \mathrm{~cm}$ layers of soil was 51.1 and $48.5 \%$, respectively, while at the end of the action period it was 49.3 and $47.1 \%$ in the $0-30$ and $30-50 \mathrm{~cm}$ layers of soil. 
In the variants of 10 and $20 \mathrm{t} /$ ha of manure on the background of mineral fertilizers, the porosity of the soil under the influence of applied manure at the end of the action period in layers $0-30$ and 30-50 $\mathrm{cm}$ was 49.3-50.7 and 47.1-47.8\%, respectively. These figures were found to be higher by $1.4-2.2$ and $0.7-1.4 \%$ than the control variant.

Composts were found to have a positive effect on soil porosity when applied at a rate of 20 $\mathrm{t} / \mathrm{ha}$. In the 7 th variant with 20 tons of compost- 2 per hectare, the porosity of the soil at the beginning of the action period was 53.3 and $50.7 \%$, respectively, which is 2.2 and $2.2 \%$ higher than in the control variant (1), 0.4 and $0.3 \%$ higher than in option (3), where $20 \mathrm{t} /$ ha manure was applied. This indicates that the water-physical condition of the soil improves when composts are used compared to usage of only manure.

At the same time, in the experiment the effect of various prepared compost standards on soil fertility - the total amount of humus, nitrogen and phosphorus in it, was found.

In the experiment, it was found that at the end of the cotton action period in the control (NRK) variant, the humus content in the $0-30$ and $30-50 \mathrm{~cm}$ layers of soil was 0.905 and $0.746 \%$, respectively. It was also found that the total nitrogen and phosphorus content in this variant was $0.074-0.062$ and $0.142-$ $0.115 \%$, respectively, for the soil layers.

In the variants applied with 10 and $20 \mathrm{t} / \mathrm{ha}$ of manure on the background of mineral fertilizers (NRK), the amount of humus in the soil layers 0-30 and $30-50 \mathrm{~cm}$ at the end of the cotton action period was $0.950-1.015$ and $0.757-0.766 \%$, increased by $0.038-0.103 \%$ at $0-30 \mathrm{~cm}$ compared to the initial state. As a result of the increase in the applied manure norms, a relative increase in the amount of humus in the ploughing (0-30) layer of soil was observed.

It was also found that the total nitrogen content in this $20 \mathrm{t} / \mathrm{ha}$ manure used variant also increased by $0.008-0.011 \%$, as the total nitrogen depends on the humus content of the soil. The total amount of phosphorus in the ploughing layer of the soil increased by $0.015-0.020 \%$, while in the lower layer of ploughing these parameters did not change.

Compost - 1 in the variants applied to 10 and $20 \mathrm{t} / \mathrm{ha}$, the amount of humus in the $0-30$ and 30-50 $\mathrm{cm}$ layers of soil was $0.960-0.762$, respectively; $1,018-0,770 \%$, total nitrogen - 0,080-0,064; 0.083 $0.065 \%$ and phosphorus - 0.148-0.118; 0.154$0.118 \%$, while compost -2 in the (6-7) variants applied to 10 and 20 t/ha was $0.970-0.760$, respectively; $1,020-0,772 \%$, total nitrogen - 0,0790,$063 ; 0.084-0.065 \%$ and phosphorus - $0.149-0.117$; $0.156-0.118 \%$ and the amount of humus in the compost - 310 and $20 \mathrm{t} / \mathrm{ha}$ in proportion to the soil layers was $0.945-0.759 ; 1,013-0,765 \%$, nitrogen $0,077-0,062 ; 0.080-0.064 \%$ and phosphorus - 0.149 $0.117 ; 0.157-0.117 \%$.

It should be noted that the optimal effect of different compost standards on changes in the amount of humus, total nitrogen and phosphorus in the soil was observed in the variant using compost-2 at $20 \mathrm{t} / \mathrm{ha}$. In this variant, it was found that the amount of humus in the $0-30 \mathrm{~cm}$ layer increased by $0.115 \%$, total nitrogen by $0.010 \%$ and phosphorus by $0.014 \%$ compared to the control.

\section{CONCLUSIONS}

In summary, using composts of various wastes at a rate of 20 tons per hectare resulted in a decrease in soil capacity mass and an increase in porosity. Moreover, an increase in the amount of humus, total nitrogen and phosphorus in the soil was also achieved. In general, compost has proven to be one of the main sources as an organic fertilizer in increasing and maintaining soil fertility.

\section{REFERENCES}

1. Azimboev S.A., Aliev J., Karimova L., Izbosarov B. (2009), O'tloqi-bo'z tuproqlarda tabiiy ma'danlar va kompostlarning g'o'za hosildorligiga ta`siri». // Scientific and Practical Conference. Buxara, pp. 45-46.

2. Azimbaev S.A., Berdiboev E., Sayimbetov A., Razoqov R.T. (2011), Har xil kompoziciyali kompostlarning g'o'zaga ta'siri. // Problems of using modern technologies to increase the efficiency of land and water resources. Republican scientific-practical conference. Qarshi, 910-December, pp. 205-207.

3. Qo'ziev R.K. (2002), O'zbekiston Respublikasi sug'oriladigan erlarining hozirgi holati. Scientific and Practical Conference, Part I. Samarkand, pp. 7-11.

4. http://www.aktivzem.com.ua/kompost.php.

5. www.aktivzem.com.ua/kompost.php. 